\title{
Pengawasan Represif Pemerintah Pusat dalam Pembentukan Peraturan Daerah
}

\section{Putu Dedy Putra Laksana ${ }^{1}$}

1Program Studi Magister (S2) Ilmu Hukum Fakultas Hukum Universitas Udayana, BaliIndonesia, E-mail: dedy.laksana@gmail.com

\begin{tabular}{l}
\hline Info Artikel \\
\hline Masuk: 7 januari 2019 \\
Diterima: 25 Maret 2019 \\
Terbit: 30 April 2019 \\
Keywords : \\
Control; Central Government, \\
Regional Regulation.
\end{tabular}

Kata kunci:

Pengawasan; Pemerintah Pusat; Peraturan Daerah

Corresponding Author: I Putu Dedy Putra Laksana, E-mail: dedy.laksana@gmail.com DOI : 10.24843/AC.2019.v04.i01.p11

\begin{abstract}
Constitutional Court Verdict Number 56 / PUU-XIV / 2016 have the potential to cause juridical implications in terms of carrying out control of the Regional Government. As for the purpose of this study is to analyze and find the ideal form related to the supervision of the Central Government in the formation of Regional Regulations after the issuance of the Constitutional Court Verdict Number 56 / PUU-XIV / 2016. The type of research used in this study is normative legal research. As for the implications after the issuance of the Constitutional Court Verdict Number 137 / PUU-XIV / 2016 on Central Government control in the formation of Regional Regulations namely; Contradictory to the Principles of the Unitary State, the Central Government Only has the Authority to Implement Preventive, Regional Regulations Can Only Be Applied for Judicial Review to the Supreme Court, Inhibit Central Government Policy on Deregulation, and Not in accordance with the Good Governance Principles. Whereas the conclusion is the central government can issue recommendations or recommendations to the regional government to immediately make an amendment to the regulation that is considered contrary to the provisions of the legislation higher law, public interest and decency, but if in a state of urgency the Central Government can become a defendant for judicial review of that Regional Regulation.
\end{abstract}

Abstrak
Putusan Mahkamah Konstitusi Nomor 56/PUU-XIV/2016
berpotensi menimbulkan implikasi yuridis terutama dalam hal
pengawasan pembentukan Peraturan Daerah. Adapun tujuan
studi ini adalah untuk menganalisis dan menemukan bentuk
yang ideal terkait pengawasan Pemerintah Pusat dalam
pembentukan Peraturan Daerah pasca diterbitkannya Putusan
Mahkamah Konstitusi Nomor 56/PUU-XIV/2016. Jenis
penelitian yang digunakan dalam penelitian ini adalah
penelitian hukum normatif. Adapun impilikasi pasca
diterbitkannya Putusan Mahkamah Konstitusi Nomor
137/PUU-XIV/2016 terhadap pengawasan Pemerintah Pusat
dalam pembentukan Peraturan Daerah yakni; Bertentangan
dengan Prinsip Negara Kesatuan, Pemerintah Pusat Hanya
Berwenang Melaksanakan Pengawasan Preventif, Perda Hanya
Dapat Dimohonkan Uji Materiil/Judicial Review Kepada
Mahkamah Agung, Menghambat Kebijakan Pemerintah Pusat
Tentang Deregulasi, dan Tidak Mencerminkan Prinsip Good


Governance. Pemerintah pusat dapat menerbitkan anjuran atau rekomendasi kepada Pemerintah Daerah untuk segera mengadakan perubahan terhadap Perda yang dianggap bertentangan dengan ketentuan Peraturan Perundangundangan yang lebih tinggi, kepentingan umum, dan kesusilaan, namun apabila dalam keadaan mendesak Pemerintah Pusat dapat menjadi Pemohon uji materiil terhadap Perda tersebut.

\section{Pendahuluan}

Dalam rangka penyelenggaraan negara, sebuah negara harus memiliki hukum dasar yang disebut konstitusi bisa tertulis bisa juga tidak tertulis, konstitusi tidak tertulis disebut konvensi. Indonesia sudah memiliki konstitusinya yaitu UUD 1945 yang lahir bersamaan dengan kemerdekaan negara Indonesia dan sudah mengalami amandemen sebanyak 4 (empat) kali berturut-turut, terhitung sejak tahun 1999 hingga tahun $2002 .{ }^{1}$

Salah satu prestasi yang berhasil didapatkan oleh Negara Republik Indonesia yakni, dengan dilakukannya amandemen terhadap UUD 1945. Bahwa dalam amandemen ke3 (tiga) yang dilaksanakan pada tahun 2001, dilakukan amandemen yang terkait dengan kekuasaan kehakiman, yang mana sebelum dilakukanya amandemen tersebut kewenangan kekuasaan kehakiman hanya dimiliki oleh Mahkamah Agung, dan baru kemudian pasca amandemen kewenangan kekuasaan kehakiman dibagi menjadi 2 (dua), yakni MA dan Mahkamah Konstitusi (MK) yang khusus menjalankan fungsi peradilan yang terkait dengan penyelesaian permasalahan ketatanegaraan. ${ }^{2}$ Adapun yang menjadi hal penting tekait dilakukanya pembagian kewenangan kekeuasaan kehakiman tersebut, yakni perihal kewenangan melaksanakan Pengujian peraturan perundang-undangan (Judicial Review). Khusus mengenai kewenangan MA diatur dalam ketentuan Pasal 24 A ayat (1) yang memberikan kewenangan kepada MA untuk menguji peraturan perundang-undangan dibawah undang-undang terhadap undangundang, dan diatur lebih lanjut pada ketentuan Pasal 31 UU MA.

Adapun yang menjadi fungsi utama pelaksanaan pengujian terhadap peraturan perundang-undangan yakni untuk memperbaiki, mengganti, atau meluruskan isi dari UU agar tdak bertentangan dengan UUD (konstitusi) atau peraturan perundangundangan di bawah UU agar tidak bertentangan dengan UU atau UUD, sehingga peraturan perundang-undangan tersebut dapat memberikan kepastian hukum (rechtszekerheid) dan perlindungan hukum (rechtsbescherming) serta memberikan keadilan (rechtvaardigheid) dan kemanfaatan (nuttigheid) bagi masyarakat luas. ${ }^{3}$

${ }^{1}$ Hidayat, N., \& Sari, M. (2018). Dualisme Judicial Review Peraturan Perundang-Undangan di Indonesia. Jurnal Magister Hukum Udayana (Udayana Master Law Journal), 7(3), 318-328. https://doi.org/10.24843/JMHU.2018.v07.i03.p04.

2 Simamora, J. (2013). Analisa Yuridis Terhadap Model Kewenangan Judicial Review Di Indonesia. Mimbar Hukum-Fakultas Hukum Universitas Gadjah Mada, 25(3), 388-401. https://doi.org/10.22146/jmh.16079.

3 Aziz, M. (2010). Pengujian Peraturan Perundang-Undangan Dalam Sistem Peraturan $\begin{array}{lllll}\text { Perundang-Undangan Indonesia. Jurnal Konstitusi, } & \text { 7(5), 113-150. }\end{array}$ https://doi.org/10.31078/jk\%25x. 
Bahwa berkaitan dengan hal tersebut diatas muncul polemik terkait dengan pengujian Peraturan Perundang-undangan dibawah Undang-Undang terhadap Undang-Undang (dalam hal ini Peraturan Daerah), yaitu akibat berlakunya Undang-Undang Nomor 23 Tahun 2014 Tentang Pemerintahan Daerah sebagaimana telah diubah dengan UndangUndang Nomor 2 Tahun 2015 tentang Penetapan Peraturan Pemerintah Pengganti Undang-Undang Nomor 2 Tahun 2014 tentang Perubahan Atas Undang-Undang Nomor 23 Tahun 2014 tentang Pemerintahan Daerah Menjadi Undang-Undang dan sebagaimana telah diubah kembali dengan Undang-Undang Nomor 9 Tahun 2015 tentang Perubahan Kedua Atas Undang-Undang Nomor 23 Tahun 2014 tentang Pemerintahan Daerah (selanjutnya disebut UU Pemda) menyebabkan permasalahan terkait dengan kewenangan Pemerintah Pusat untuk melakukan pembatalan Peraturan Daerah (selanjutnya disebut Perda) karena adanya ketentuan Pasal 251 ayat (1) UU Pemda yang memberikan kewenangan kepada Pemerintah Pusat untuk membatalkan Perda, yang dinyatakan sebagai berikut:

"Peraturan Daerah Provinsi dan Peraturan Gubernur yang bertentangan dengan ketentuan peraturan perundang-undangan yang lebih tinggi, kepentingan umum, dan/atau kesusilaan dibatalkan oleh Menteri."

Bahwa terkait dengan hal tersebut Ni'matul Huda Guru Besar Universitas Islam Indonesia Yogyakarta menyampaikan bahwa Pemerintah Pusat atau Pemerintah Daerah Provinsi seharusnya hanya menguji Perda apabila statusnya masih dalam rancangan Perda yang belum mengikat secara umum. Namun apabila perda sudah mengikat umum (disahkan) sebaiknya yang berwenang mengujinya adalah lembaga peradilan (Mahkamah Agung). ${ }^{4}$ Apabila dilihat dari segi pembuatan/penyusunan Perda baik provinsi maupun Kabupaten/Kota disetarakan dengan Undang-Undang sebagai produk hukum lembaga legislatif. Sedangkan, dari sisi isi sudah seharusnya sesuai dengan lingkup kewenangan daerah bersangkutan. Sebab, tak jarang peraturan yang lebih tinggi potensial melanggar hak dan kewajiban daerah yang dijamin UUD NRI 1945 dan UU Pemda. Untuk itu wewenang pembatalan Perda seharusnya tidak ada dipundak Pemerintah, tetapi dilakukan oleh MA melalui proses pengujian Peraturan Perundang-undangan di bawah Undang-Undang. Ni' matul Huda kemudian mengatakan bahwa Pemerintah pusat (Mendagri dan Gubernur) seharusnya tetap melakukan executive review dalam bentuk evaluasi terhadap semua Rancangan Peraturan Daerah (selanjutnya disebut Ranperda) Provinsi dan Kabupaten/Kota sebelum ditetapkan Gubernur atau Bupati/Walikota. ${ }^{5}$

Terkait dengan polemik kewenangan pengujian dan/atau pembatalan Perda tersebut, Asosiasi Pemerintah Kabupaten Seluruh Indonesia (selanjutnya disebut APKASI) bersama 45 Pemerintah Kabupaten mempersoalkan beberapa Pasal dalam UU Pemda, salah satunya adalah terkait dengan ketentuan Pasal 251 ayat (2), Pasal 251 ayat (3), Pasal 251 ayat (4), Pasal 251 ayat (8) UU Pemda yang memberi kewenangan kepada Pemerintah Pusat melalui Mendagri dan Gubernur untuk membatalkan perda kabupaten/kota apabila bertentangan standar, norma, kriteria, prosedur yang ditetapkan pemerintah pusat. Pembatasan lain, pemkab dan DPRD tidak berwenang

4 ASH. (2016). Dua Ahli Ini Sebut Pembatalan Perda Wewenang Pengadilan. Available from https://www.hukumonline.com/berita/baca/lt57f4d9a226f43/dua-ahli-ini-sebutpembatalan-perda-wewenang-pengadilan. (Diakses 10 Mei 2017).

${ }^{5}$ Ibid. 
melaksanakan fungsi pengelolaan Sumber Daya Alam (SDA). Karena itu, para pemohon dalam perkara pengujian UU Pemda terhadap UUD NRI 1945 tersebut meminta MK untuk membatalkan ketentuan Pasal-pasal tersebut diatas.

Menindaklanjuti hal tersebut, MK kemudian mengabulkan permohonan tersebut dan membatalkan ketentuan Pasal 251 ayat (2), Pasal 251 ayat (3), Pasal 251 ayat (4), Pasal 251 ayat (8) UU Pemda dengan mengeluarkan Putusan Mahkmah Konstitusi Nomor 137/PUU-XIII/ 2015 tentang Pengujian Undang-Undang Nomor 23 Tahun 2014 tentang Pemerintahan Daerah terhadap Undang-Undang Dasar Negara Republik Indonesia Tahun 1945, dengan kutipan amar putusan sebagai berikut:

- “...sepanjang pengujian Pasal 251 ayat (2), ayat (3), dan ayat (8) serta ayat (4) sepanjang frasa “...pembatalan Perda Kabupaten/Kota dan peraturan bupati/wali kota sebagaimana dimaksud pada ayat (2) ditetapkan dengan keputusan gubernur sebagai wakil Pemerintah Pusat"..

- Menyatakan frasa "Perda Kabupaten/Kota dan" dalam Pasal 251 ayat (2) dan ayat (4), frasa "Perda Kabupaten/Kota dan/atau" dalam Pasal 251 ayat (3), dan frasa "penyelenggara Pemerintah Daerah kabupaten/kota tidak dapat menerima keputusan pembatalan Perda Kabupaten/Kota dan" dan frasa "Perda Kabupaten/Kota atau" dalam Pasal 251 ayat (8) UU Pemda bertentangan dengan UUD NRI 1945 dan tidak mempunyai kekuatan hukum mengikat..."6

Bahwa terkait dengan hal yang sama, MK kemudian mengeluarkan Putusan Mahkamah Konstitusi Nomor 56/PUU-XIV/2016 tentang Pengujian Undang-Undang Nomor 23 Tahun 2014 tentang Pemerintahan Daerah terhadap Undang-undang Dasar Negara Republik Indonesia Tahun 1945, yang dalam amar putusannya MK menyatakan bahwa Pasal 251 ayat (1) dan Pasal 251 ayat (4) UU Pemda yang mengatur mengenai pembatalan perda provinsi melalui mekanisme executive review maka pertimbangan hukum dalam Putusan Nomor 137/PUU-XIII/2015, tertanggal 5 April 2017 berlaku pula untuk permohonan para pemohon dalam Putusan Mahkamah Konstitusi Nomor 56/PUU-XIV/2016. Sehingga Mahkamah Berpendapat, Pasal 251 ayat (1) dan Pasal 251 ayat (4) UU Pemda bertentangan dengan UUD 1945.

Berdasarkan uraian latar belakang tersebut, maka perlu dikaji dan di analisis permasalahan tersebut atas dengan mengidentifikasi instrumen hukum nasional Indonesia dalam menyikapi persoalan mengenai pengawasan pembentukan Peraturan Daerah pasca diterbitkannya Putusan Mahkamah Konstitusi Nomor 56/PUUXIV/2016.

\section{Metode Penelitian}

Jenis penelitian yang digunakan adalah penelitian hukum normatif. Penelitian hukum normatif adalah penelitian hukum yang meletakan hukum sebagai sebuah bangunan sistem norma. Sistem norma yang dimaksud adalah mengenai asas-asas, norma, kaidah dari peraturan perundang-undangan, putusan pengadilan, perjanjian, serta

\footnotetext{
${ }^{6}$ Ibid. h. 211.
} 
doktrin atau ajaran. ${ }^{7}$ Pendekatan yang digunakan adalah pendekatan perundangundangan (statute approach), pendekatan konsep (conceptual approach), Pendekatan Filsafat (philosophical approach), dan pendekatan kasus (case approach). Teknik analisis bahan hukum yang penulis gunakan dalam penelitian ini akan dilakukan secara deskriptif, interpretatif, evaluatif, sistematif dan argumentatif karena dalam penelitian ini akan diteliti secara mendalam mengenai suatu permasalahan hukum tentang kewenangan Judicial Review terhadap Peraturan Daerah, yang kemudian akan dibandingkan dengan suatu pandangan ahli hukum, pernyataan, rumusan norma, keputusan, baik yang tertera dalam hukum primer maupun dalam hukum sekunder yang berkaitan dengan permasalahan yang penulis teliti, serta mencari kaitan rumus suatu konsep hukum atau konsep hukum antara perundang-undangan yang sederajat maupun tidak sederajat, baru kemudian di evaluasi dan dijabarkan dalam suatu penelitian ilmiah yang berdasarkan pada alasan-alasan yang bersifat penalaran hukum.

\section{Hasil dan Pembahasan}

\subsection{Implikasi Diterbitkannya Putusan Mahkamah Konstitusi Nomor 56/PUU- XIV/2016 Terhadap Pengawasan Pemerintah Pusat Dalam Pembentukan Peraturan Daerah}

Dalam Pasal 10 ayat (1) UU Nomor 24 Tahun 2003 ditentukan bahwa Mahkamah Konstitusi berwenang mengadili pada tingkat pertama dan terakhir yang putusannya bersifat final. Selanjutnya dalam Pasal 47 ditentukan bahwa putusan Mahkamah Konstitusi memperoleh kekuatan hukum tetap sejak selesai diucapkan dalam sidang pleno terbuka untuk umum. Itu berarti bahwa putusan Mahkamah Konstitusi langsung memperoleh kekuatan hukum tetap sejak diucapkan dan tidak ada upaya hukum yang dapat ditempuh. Oleh karena itu, putusan Mahkamah Konstitusi bersifat final and binding. ${ }^{8}$

Diterbitkannya Putusan Mahkamah Konstitusi Nomor 56/PUU-XIV/2016 yang membatalkan wewenang Pemerintah Pusat dalam melakukan pengawasan repesif terhadap Pemerintah Daerah dalam membentuk Perda sebagaimana diatur dalam Pasal 251 UU Pemda tentunya tidak lepas dari kritik dan reaksi pro kontra, Hal tersebut ditunjukan dengan adanya dissenting opinions oleh 4 (empat) orang Hakim Konstitusi. Putusan MK tersebut menimbulkan berbagai implikasi yuridis dalam hal pelaksanaan pengawasan terhadap Pemerintah Daerah dalam hal pengawasan terhadap pembentukan Perda agar tidak menyimpang dari kebijakan yang sudah ditetapkan oleh Pemerintah Pusat sebagai pemegang kedaulatan tertinggi dalam sebuah Negara Kesatuan, kepentingan umum dan kesusilaan, selain itu putusan tersebut telah menimbulkan kekosongan norma dalam hal pengawasan represif pemerintah pusat terhadap pembentukan Perda, yang mana MK telah membatalkan

\footnotetext{
${ }^{7}$ Fajar, M. (2010). Dualisme Penelitian Hukum Normatif \& Empiris. Yogyakarta: Pustaka Pelajar. h. 34 .

8 Ngastawa, I. (2015). Implikasi Putusan Mahkamah Konstitusi Nomor 11-017/PUU-I/2003 Terhadap Perlindungan Hukum Hak Dipilih. Jurnal Magister Hukum Udayana (Udayana Master Law Journal), 4(4). https://doi.org/10.24843/JMHU.2015.v04.i04.p15.
} 
kewenangan untuk melakukan pengawasan represif dalam pembentukan Perda Putusan Mahkamah Konstitusi Nomor 56/PUU-XIV/2016, antara lain:

\section{1) Bertentangan dengan Prinsip Negara Kesatuan.}

Sejak diberlakukannya UUD NRI 1945 sebagai Konstitusi Negara Republik Indonesia hingga diadakannya amandemen sekarang, konstitusi ini memberikan pesan bahwa Negara Republik Indonesia dibangun dalam sebuah kerangka negara yang berbentuk kesatuan (unitary), bukan berbentuk federasi (serikat). ${ }^{9}$ Dalam negara kesatuan bagianbagian negara itu lazim disebut dengan daerah, sedangkan istilah daerah ini merupakan istilah teknis bagi penyebutan suatu bagian teritorial yang berpemerintahan sendiri dalam rangka melaksanakan negara kesatuan tersebut. ${ }^{10}$ Adapun asas yang dianut dalam negara kesatuan terdapat asas bahwa segenap urusan-urusan negara tidak dibagi antara Pemerintah Pusat (centeral government) dengan pemerintah lokal (local government) sedemikian rupa, sehingga urusan-urusan dalam negara kesatuan tetap merupakan suatu kebulatan (eenheid) dan bahwa pemegang kekuasaan tertinggi di negarai itu ialah Pemerintah Pusat.

Pada negara yang berbentuk kesatuan, Pemerintah Pusat bertanggung jawab untuk menjamin keutuhan negara kesatuan, karenanya harus dapat menjamin pelayanan yang sama atau keseragaman kepada seluruh rakyat (asas uniformitas), sehingga karena tanggung jawabnya ini penyelenggaraan Pemerintah Pusat cenderung bersifat sentralistik. ${ }^{11}$ Akan tetapi karena sistem pemerintah Negara Republik Indonesia salah satunya menganut asas negara kesatuan yang didesentralisasikan, maka ada tugastugas tertentu yang diurus sendiri, sehingga menimbulkan hubungan timbal balik yang melahirkan adanya hubungan kewenangan dan pengawasan. ${ }^{12}$

Sesuai dengan perspektif Negara Kesatuan atau unitary state sebagaimana yang telah diuraikan diatas, sangat logis dan tepat apabila Pemerintah pusat berwenang untuk melakukan kontrol (pengawasan) terhadap Pemerintah Daerah. Adapun kewenangan pengawasan oleh Pemerintah Pusat adalah weweanang untuk melakukan pengawasan atas norma hukum yang dibentuk dan ditetapkan oleh Pemerintah Daerah yang dikenal dengan istilah "executive review", selain itu karena kedudukan hukum (rechtpositie) daerah otonom adalah sub sistem negara kesatuan dan otonomi, bukan dalam arti kemerdekaan yang lepas dari ikatan negara kesatuan, maka pengawasan terhadap penyelenggaraan pemerintahan daerah tidak dapat diabaikan.

Sangat tepat apabila memberikan kewenangan kepada Pemerintah Pusat dalam melaksankan pengawasan represif terhadap Pemerintah Pusat dalam pembentukan Perda, melalui menteri dan gubernur sebagai wakil pemerintah pusat di daerah.

\footnotetext{
${ }^{9}$ Rudiani, N. (2017). Pengaruh Amandemen Keempat Undang-Undang Dasar Negara Republik Indonesia Tahun 1945 Terhadap Pemerintahan Daerah. Jurnal Magister Hukum Udayana (Udayana Master Law Journal), 6(1), 120-135. https://doi.org/10.24843/JMHU.2017.v06.i01.p10. ${ }^{10}$ Huda, N. M. (2017). Hukum Pemerintahan Daerah. Bandung: Nusa Media. h. 29.

11 Anggriani, J. (2011). Kedudukan Qanun dalam Sistem Pemerintahan Daerah dan Mekanisme Pengawasannya. Jurnal Hukum Ius Quia Iustum, 18(3), 320-335. https://doi.org/10.20885/iustum.vol18.iss3.art2.

12 Manan, B. (1993). Perjalanan Historis Pasal 18 UUD 1945. Bandung: UNISKA. h. 3.
} 
Hakikat pembatalan dalam hukum administrasi yaitu tindakan hukum dalam hal keputusan yang dibuat pejabat pemerintahan mengandung cacat hukum atau tidak lagi memenuhi syarat, substantif maupun formal. Tujuannya yakni untuk melindungi pihak-pihak dan masyarakat yang dirugikan atas suatu keputusan pemerintahan dan memulihkan kembali atau menegasikan akibat hukum yang timbul dari sebuah keputusan. Pembatalan dapat dilakukan oleh pejabat yang membuat keputusan, atasan pejabat yang membuat keputusan, atau pengadilan. Meskipun dalam hukum administrasi tindakan pembatalan digunakan terhadap keputusan (beschikking), dalam konteks pembatalan Perda kabupaten/kota oleh presiden melalui Mendagri dan/atau gubernur rasionalitas hukumnya dapat diterima apabila pembatalan diberlakukan terhadap Perda. Sebab, menurut Pasal 1 angka 1 UU Pemda menyatakan pemerintah pusat adalah Presiden RI yang memegang kekuasaan pemerintahan negara Republik Indonesia yang dibantu Wakil Presiden dan menteri sebagaimana dimaksud UUD NRI 1945 atau dengan lain perkataan, presiden adalah penanggung jawab keseluruhan pelaksanaan pemerintahan. Oleh karena, Indonesia adalah negara kesatuan sebagaimana ditegaskan dalam Pasal 1 ayat (1) UUD NRI 1945. Pemerintah daerah adalah bagian dari pelaksanaan pemerintahan. Sehingga, meskipun berdasarkan Pasal 18 UUD NRI 1945 daerah diberi otonomi yang seluas-luasnya untuk menyelenggarakan pemerintahan, penanggung jawab terakhir penyelenggaran pemerintahan itu tetap Presiden.

\section{2) Pemerintah Pusat Hanya Berwenang Melaksanakan Pengawasan Preventif Terhadap Pemerintah Daerah Dalam Pembentukan Perda}

Bahwa pasca diterbitkannya Putusan Mahkamah Konstitusi Nomor 56/PUU-XIV/2016 adalah dibatalkannya kewenangan Pemerintah Pusat dalam melaksanakan pengawasan represif terhadap Pemda dalam pembentukan Perda. Adapun dasar hukum pelaksanaan Pengawasan represif oleh Pemerintah Pusat dilakukan berdasarkan pada ketentuan Pasal 250 ayat (1) UU Pemda yang menyatakan bahwa Perda dan Perkada dilarang bertentangan dengan ketentuan peraturan perundangundangan yang lebih tinggi, kepentingan umum, dan/atau kesusilaan.

\section{3) Perda Hanya Dapat Dimohonkan Uji Materiil/Judicial Review Kepada MA}

Dibatalkannya kewenangan pemerintah dalam melakukan pengawasan represif terhadap Perda kabupaten/kota oleh Mahkamah Konstitusi melalui Putusan Mahkamah Konstitusi Nomor 56/PUU-XIV/2016, menjadikan MA satu-satunya lembaga negara yang berwenang melaksanakan Judicial Review terhadap Perda Provinsi, dan Kabupaten/Kota. Perlu diketahui bahwa wewenang pengujian yang dimiliki oleh MA sebagimana dinyatakan Pasal 2 ayat (3) Perma No. 1 Tahun 2011 bahwa peraturan perundang-undangan di bawah undang-undang (Perda kabupaten/kota) yang dapat diajukan keberatan adalah yang diduga bertentangan dengan suatu peraturan perundang-undangan yang tingkatnya lebih tinggi. Dengan demikian dasar pengujian Perda oleh MA hanya atas dugaan bertentangan dengan peraturan perundang-undangan yang lebih tinggi. Sehingga apabila dibandingkan dengan apa yang dapat dilakukan Pemerintah Pusat sebelum adanya pembatalan kewenangan oleh MK akibat permohonan uji materi Pasal 251 UU Pemda yakni dapat melakukan pengawasan represif terhadap Perda Provinsi dan Kabupaten/Kota yang bertentangan dengan ketentuan peraturan perundang-undangan yang lebih tinggi, kepentingan umum, dan/atau kesusilaan. Dengan demikian kepentingan masyarakat 
lebih dapat dilindungi dan mempersempit celah berlakunya Perda kabupaten/kota yang sewenang-wenang dan merugikan masyarakat.

\section{4) Menghambat Kebijakan Pemerintah Pusat Tentang Deregulasi}

Dengan dicabutnya kewenangan pengawasan represif pemerintah pusat akibat dikabulkannya permohonan uji materiil Pasal 251 UU Pemda oleh MK maka pemerintah pusat telah kehilangan instrumen hukum dalam melakukan pengawasan represif terhadap Perda Provinsi dan Kabupaten/Kota yang menghambat iklim investasi atau kebijakan-kebijakan pemerintah pusat. Implikasinya, pemerintah daerah akan semakin sulit dikontrol, bahkan ke depannya bakal muncul banyak regulasi baru yang bertabrakan dengan keinginan pemerintah pusat menciptakan iklim investasi yang sehat. MK dalam putusan tersebut hanya fokus pada aspek legalnya saja, tanpa melihat aspek efektifitas dan dinamika di daerah. Padahal, selama ini banyak regulasi yang dibuat Pemda cenderung bermasalah dan menyulitkan pelaku usaha.

\section{5) Tidak Mencerminkan Prinsip Good Governance}

Apabila dikaji dari sudut pandang good governance yang mana dari sudut hukum positif Indonesia, prinsip-pirinsip good governance adalah 7 (tujuh) prinsip sebagaimana yang diatur dalam ketentuan Pasal 3 yang Undang-Undang Nomor 28 Tahun 1999 tentang Penyelenggara Negara Yang Bersih dan Bebas Korupsi Kolusi dan Nepotisme ${ }^{13}$ yang meliputi asas kepastian hukum, asas tertib penyelenggaraan negara, asas kepentingan umum, asas keterbukaan, asas proporsionalitas, asas profesionalitas dan asas akuntabilitas. Prinsip-prinsip tersebut berlaku bagi seluruh penyelenggara negara baik yang melaksanakan fungsi legislatif, eksekutif maupun yudisial.

Dalam konteks membangun manajemen pemerintahan publik yang bercirikan good governance pengawasan merupakan aspek penting untuk menjaga fungsi pemerintahan berjalan sebagaimana mestinya. Dalam konteks ini, pengawasan menjadi sama pentingnya dengan penerapan good governance itu sendiri. ${ }^{14}$

Bahwa dengan dibatalkannya kewenangan Pemerintah Pusat dalam melaksanakan pengawasan represif terhadap Perda Provinsi dan Kabupaten/Kota yang saat ini hanya menyisakan MA sebagai lembaga negara yang berwenang untuk melaksanakan uji materiil terhadap Perda Provinsi dan Kabupaten/Kota dengan berbagai keterbatasan yang dimilikinya sebagaimana diuraikan sebelumnya, baik dari segi sumberdaya maupun dari yuridis formal berkaitan dengan mekanisme pengawasan represif yang dimiliki, sangat tidak mencerminkan penerapan prinsip-prinsip good governance tersebut. Utamanya asas kepastian hukum, kepentingan umum, keterbukaan dan akuntabilitas.

\subsection{Pengawasan Pemerintah Pusat Dalam Pembentukan Peraturan Daerah Pasca Putusan Mahkamah Konstitusi Nomor 56/PUU-XIV/2016}

13 Wairocana, I. G. N. (2005). Good Governance (Kepemerintahan Yang Baik) Dan Implementasinya Di Dalam Penyelenggaraan Pemerintahan Daerah. Doctoral Dissertation. Universitas Airlangga.

14 Suparta, I. (2013). Pengawasan Terhadap Pramuwisata Di Provinsi Bali. Jurnal Magister Hukum Udayana (Udayana Master Law Journal), 2(1). https://doi.org/10.24843/JMHU.2013.v02.i01.p11. 
Bahwa sebagai konsekuensi dari prinsip pemisahan kekuasaan dengan sistem check and balances sebagaimana yang dianut oleh Negara Republik Indonesia serta diterbitkannya Putusan Mahkamah Konstitusi Nomor 56/PUU-XIV/2016 yang menghapus kewenangan Pemerintah Pusat dalam melakukan pengawasan Represif terhadap Perda, harus ditentukan lembaga negara mana yang berwenang untuk melakukan pengawasan represif terhadap Perda.

Bahwa mengingat Perda dibuat oleh satuan Pemerintan yang mandiri (otonom), dengan lingkungan wewenang yang mandiri pula, maka dalam pengujiannya terhadap Peraturan Perundang-undangan yang lebih tinggi tidak boleh semata-mata berdasarkan "pertingkatan", melainkan juga pada "lingkungan wewenangnya". Suatu Perda yang bertentangan dengan suatu Peraturan Perundang-undangan yang lebih tinggi tingkatannya (kecuali UUD) belum tentu salah, kalau ternyata Peraturan Perundang-undangan yang lebih tinggi tingkatannya yang melanggar hak dan kewajiban daerah yang dijamin oleh UUD NRI 1945 atau UU Pemda, dan meskipun daerah-daerah di Negara Republik Indonesia yang menganut prinsip negara kesatuan bukan merupakan unit-unit negara bagian yang tersendiri, tetapi rakyat di daerah memiliki kedaulatannya tersendiri dalam lingkungan Daerah Provinsi dan Kabupaten/Kota, disamping kedaulatan dalam konteks bernegara kesatuan Negara Republik Indonesia berdasarkan UUD NRI 1945.

Oleh kerena produk-produk hukum di daerah Provinsi dan daerah Kabupaten/Kota yang merupakan hasil kerja Kepala Daerah bersama-sama dengan DPRD yang dipilih langsung oleh rakyat melalui Pemilihan Umum dan Pemilihan Kepala Daerah, maka kewenangan pembatalan terhadap suatu Perda sesuai dengan prinsip pemisahan kekuasaan dengan sistem check and balances yang dianut oleh negara Republik Indonesia sudah seharusnya melibatkan lembaga Yudisial dalam pelaksanaanya, sehingga pelaksanaan pembatalan terhadap suatu Perda terhindar dari pergulatan kepentingan anatara cabang-cabang kekuasaan legislatif dan eksekutif, baik di tingkat daerah maupun pusat, serta terwujud suatu mekanisme pengujian Perda yang bersifat objektif dan imparsial.

Dalam perspektif negara kesatuan, adalah logis apabila mengembangkan pemikiran bahwa Pemerintah atasan berwenang untuk melakukan kontrol terhadap unit pemerintahan bawahan, artinya, pemerintah pusat dalam Negara Kesatuan Republik Indonesia berdasarkan UUD NRI 1945 tentu dapat dikatakan mempunyai kewenangan untuk mengontrol unit-unit pemerintahan daerah Provinsi, demikian pula pemerintahan daerah Provinsi juga dapat diberi kewenangan tertentu dalam rangka mengendalikan jalannya pemerintahan daerah Kabupaten/Kota.

Konsepsi pemerintahan daerah bukanlah dalam artian sebuah lembaga, melainkan menunjuk pada tempat proses penyelenggaraan urusan atau tugas negara, yakni di daerah sebagai perpanjangan penyelenggaraan pemerintahan oleh Pemerintah Pusat. ${ }^{15}$ Setelah lahirnya otonomi daerah, dalam rangka untuk menampung aspirasi masyarakat di daerah, kepentingan umum dalam penafsirannya harus disesuaikan dengan masyarakat setempat, sikap pemerintah tidak dibenarkan secara parsial

15 Utama, M. A. (2007). Hukum Lingkungan. Denpasar: Pustaka Sutra. h. 37. 
memihak bagi golongan tertentu saja, tetapi dilakukan secara menyeluruh untuk kepentingan masyarakat. ${ }^{16}$

Adapun objek Pelaksanaan pengawasan oleh Pemerintah Pusat adalah pengawasan terhadap norma hukum. Mekanisme pengawasan norma hukum inilah yang biasanya disebut dengan sistem "abstract review" yang dapat dilakukan oleh lembaga eksekutif, legislatif dan lembaga yudisial. Jika "abstract review" itu dilakukan oleh lembaga eksekutif, maka disebut dengan "executive review". Jika "abstract review" itu dilakukan oleh lembaga legislatif, maka disebut dengan "legislative review", dan apabila "abstract review" itu dilakukan oleh lembaga yudisial, maka hal tersebut biasa disebut sebagai "judicial review".

Secara terminologis, istilah pengawasan sering disebut dengan istilah controlling, evaluating, appraising, correcting, dan control. ${ }^{17}$ Apabila ditinjau dari hubungan antara Pemerintah Pusat dengan Pemerintah Daerah, pengawasan merupakan "pengikat" kesatuan, agar bandul kebebasan berotonomi tidak bergerak begitu jauh sehingga mengurangi bahkan mengancam kesatuan. Apabila pengikat tersebut ditarik begitu kencang, napas kebebasan desentralisasi akan terkurangi bahkan mungkin terputus.

Disamping "abstract review", mekanisme kontrol norma juga dapat dilakukan melalui prosedur "abstract preview", yaitu kontrol yang dilakukan sebelum suatu norma hukum yang bersangkutan mengikat untuk umum. Misalnya suatu rancangan Perda disahkan oleh perlemen tetapi sebelum diundangkan sebagaimana mestinya, Pemerintah Pusat diberi kewenangan untuk menguji, menilai, atau bahkan menolak pengesahan Perda. Mekanisme demikian dapat disebut sebagai "executive abstract preview".

Kewenangan "executive abstract preview" inilah yang masih bisa dilaksanakan oleh Pemerintah Pusat pasca diterbitkannya Putusan Mahkamah Konstitusi Nomor 56/PUU-XIV/2016, executive abstract preview adalah upaya untuk menghindari terjadinya kekelirua-kekeliruan, baik sengaja maupun tidak disengaja dalam pembentukan suatu Perda, yang mana tindakan pengawasan tersebut lazim disebut sebagai usaha preventif, namun demikian apabila executive review diartikan sebagai penilaian atau pengujian Peraturan Perundang-undangan oleh pihak Pemerintah Pusat, maka segala bentu produk hukum Pemerintah Pusat maupun Pemerintah Daerah di uji oleh Pemerintah itu sendiri yang bersifat kelembagaan dan hirarkis. Dalam konteks ini, objek executive review lebih terhadap produk hukum yang bersifat abstrak dan mengatur, serta mengikat secara umum (regeling), dan di luar itu yakni yang bersifat beschikking menjadi objek lembaga Yudisial (Pengadilan Tata Usaha Negara).

Pelaksanaan pengawasan/kontrol terhadap produk hukum pemerintah khususnya Pemerintah Daerah baik yang bersifat internal maupun eksternal sangat penting dilakukan, sebab segala tindakan/perbuatan hukum pemerintah berkaitan dengan

16 Budiartha, G. (2015). Dualisme Pembatalan Peraturan Daerah Provinsi Dengan Peraturan Presiden Dan Peraturan Menteri Dalam Negeri. Jurnal Magister Hukum Udayana (Udayana Master Law Journal), 4(1). https:// doi.org/10.24843/JMHU.2015.v04.i01.p01.

17 Fauzan, M. (2006). Hukum Pemerintahan Daerah Kajian Tentang Hubungan Keuangan antara Pusat dan Daerah. Yogyakarta: UII Press. h. 90. 
tindakan/perbuatan administrasi negara yang dijalankan oleh organ pemerintahan dan salah satunya oleh Pemerintah. Sebagaimana diketahui bahwa fungsi Pemerintah dalam arti eksekutif tidak hanya melaksanakan perintah Undang-Undang, namun juga menyangkut pada pelayanan kapada masyarakat dan peningkatan kesejahteraan masyarakat.

Jadi dengan demikian maka segala tindakan/perbuatan administrasi negara yang dijalankan oleh Pemerintah Daerah khusunya dalam pembentukan Perda wajib dilakukan pengawasan oleh Pemerintah Pusat dengan melakukan pendekatan perubahan ataupun dengan mencabut Perda tersebut kemudian menggantinya dengan Perda yang baru, hal ini dilakukan sebagai tindak lanjut dari Putusan Mahkamah Konstitusi Nomor 56/PUU-XIV/2016, serta untuk menjaga sinkronisasi antara kebijakan yang telah ditentukan oleh Pemerintah Pusat dengan produk hukum yang di bentuk oleh Pemerintah Daerah, serta agar produk hukum daerah tersebut mencerminkan tertib hukum dan kepastian hukum, agar dapat memenuhi rasa keadilan masyarakat atas perubahan sosial-ekonomi.

Bahwa selain hal tersebut diatas, apabila dikemudian hari ditemukan Perda yang sudah berlaku dimasyarakat yang bertentangan dengan ketentuan Peraturan Perundang-undangan yang lebih tinggi, kepentingan umum, dan kesusilaan, Pemerintah pusat dapat menerbitkan anjuran atau rekomendasi yang didalamnya tercantum pula hasil evaluasi Pemerintah Pusat terhadap Perda tersebut, kepada Pemerintah Daerah untuk segera mengadakan perubahan terhadap Perda yang dianggap bertentangan dengan ketentuan Peraturan Perundang-undangan yang lebih tinggi, kepentingan umum, dan kesusilaan, namun apabila dalam keadaan mendesak Pemerintah Pusat dapat menjadi Pemohon uji materiil terhadap Perda yang bertentangan dengan ketentuan Peraturan Perundang-undangan yang lebih tinggi, kepentingan umum, dan kesusilaan di MA.

\section{Kesimpulan}

Terdapat 5 (lima) impilikasi pasca diterbitkannya Putusan Mahkamah Konstitusi Nomor 56/PUU-XIV/2016 terhadap pengawasan Pemerintah Pusat dalam pembentukan Peraturan Daerah, adalah sebagai berikut: Adapun impilikasi pasca diterbitkannya Putusan Mahkamah Konstitusi Nomor 137/PUU-XIV/2016 terhadap pengawasan Pemerintah Pusat dalam pembentukan Peraturan Daerah yakni; Bertentangan dengan Prinsip Negara Kesatuan yang dianut oleh Negara Republik Indonesia, Pemerintah Pusat Hanya Berwenang Melaksanakan Pengawasan Preventif Terhadap Pemerintah Daerah Dalam Pembentukan Perda, Perda Hanya Dapat Dimohonkan Uji Materiil/Judicial Review Kepada MA, Menghambat Kebijakan Pemerintah Pusat Tentang Deregulasi, dan Tidak Mencerminkan Prinsip Good Governance. Apabila dikemudian hari ditemukan Perda yang sudah berlaku dimasyarakat yang bertentangan dengan ketentuan Peraturan Perundang-undangan yang lebih tinggi, kepentingan umum, dan kesusilaan, Pemerintah pusat dapat menerbitkan anjuran atau rekomendasi yang didalamnya tercantum pula hasil evaluasi Pemerintah Pusat terhadap Perda tersebut kepada Pemerintah Daerah untuk segera mengadakan perubahan terhadap Perda yang dianggap bertentangan dengan 
ketentuan Peraturan Perundang-undangan yang lebih tinggi, kepentingan umum, dan kesusilaan, namun apabila dalam keadaan mendesak Pemerintah Pusat dapat menjadi Pemohon uji materiil terhadap Perda yang bertentangan dengan ketentuan Peraturan Perundang-undangan yang lebih tinggi, kepentingan umum, dan kesusilaan di Mahkamah Agung.

\section{Daftar Pustaka}

\section{Buku}

Asshidiqie, J. (2010). Perkembangan Dan Konsolidasi Lembaga Negara Pasca Reformasi. Jakarta: Sinar Grafika.

Fajar, M. (2010). Dualisme Penelitian Hukum Normatif \& Empiris. Yogyakarta: Pustaka Pelajar.

Fauzan, M. (2006). Hukum Pemerintahan Daerah Kajian Tentang Hubungan Keuangan antara Pusat dan Daerah. Yogyakarta: UII Press.

Huda, N. M. (2017). Hukum Pemerintahan Daerah. Bandung: Nusa Media.

Manan, B. (1993). Perjalanan Historis Pasal 18 UUD 1945. Bandung: UNISKA.

Utama, M. A. (2007). Hukum Lingkungan. Denpasar: Pustaka Sutra.

\section{Tesis/Disertasi}

Wairocana, I. G. N. (2005). Good Governance (Kepemerintahan Yang Baik) Dan Implementasinya Di Dalam Penyelenggaraan Pemerintahan Daerah. Doctoral Dissertation. Universitas Airlangga.

\section{Jurnal}

Anggriani, J. (2011). Kedudukan Qanun dalam Sistem Pemerintahan Daerah dan Mekanisme Pengawasannya. Jurnal Hukum Ius Quia Iustum, 18(3), 320-335. https://doi.org/10.20885/iustum.vol18.iss3.art2.

Aziz, M. (2010). Pengujian Peraturan Perundang-Undangan Dalam Sistem Peraturan Perundang-Undangan Indonesia. Jurnal Konstitusi, 7(5), 113-150. https://doi.org/10.31078/jk\%25x.

Budiartha, G. (2015). Dualisme Pembatalan Peraturan Daerah Provinsi Dengan Peraturan Presiden Dan Peraturan Menteri Dalam Negeri. Jurnal Magister Hukum Udayana Master Lawana Journal), 4(1). https:// doi.org/10.24843/JMHU.2015.v04.i01.p01.

Hidayat, N., \& Sari, M. (2018). Dualisme Judicial Review Peraturan PerundangUndangan di Indonesia. Jurnal Magister Hukum Udayana (Udayana Master Law Journal), 7(3), 318-328. https://doi.org/10.24843/JMHU.2018.v07.i03.p04.

Ngastawa, I. (2015). Implikasi Putusan Mahkamah Konstitusi Nomor 11-017/PUUI/2003 Terhadap Perlindungan Hukum Hak Dipilih. Jurnal Magister Hukum Udayana (Udayana Master Law Journal), https://doi.org/10.24843/JMHU.2015.v04.i04.p15.

Rudiani, N. (2017). Pengaruh Amandemen Keempat Undang-Undang Dasar Negara Republik Indonesia Tahun 1945 Terhadap Pemerintahan Daerah. Jurnal Magister Hukum Udayana (Udayana Master Law Journal), 6(1), 120-135. https://doi.org/10.24843/JMHU.2017.v06.i01.p10.

Simamora, J. (2013). Analisa Yuridis Terhadap Model Kewenangan Judicial Review Di Indonesia. Mimbar Hukum-Fakultas Hukum Universitas Gadjah Mada, 25(3), 388-401. https://doi.org/10.22146/jmh.16079. 
Suparta, I. (2013). Pengawasan Terhadap Pramuwisata Di Provinsi Bali. Jurnal Magister Hukum Udayana (Udayana Master Law Journal), 2(1). https://doi.org/10.24843/JMHU.2013.v02.i01.p11.

\section{Website}

ASH. (2016). Dua Ahli Ini Sebut Pembatalan Perda Wewenang Pengadilan. Available from https://www.hukumonline.com/berita/baca/lt57f4d9a226f43/dua-ahli-ini-sebutpembatalan-perda-wewenang-pengadilan. (Diakses 10 Mei 2017). 